\title{
Article \\ PREVENTIVE ACTIVITY OF THE EXTRACT OF THE ULOMOIDES DERMESTOIDES DARKLING BEETLE IN THE DIET OF C57BL/6JSTO MICE IN A NEUROTOXIC MODEL OF PARKINSON'S DISEASE
}

\author{
Vladimir M.Kovalzon ${ }^{1 *}$, Aleksandr V.Ambaryan"1, Aleksandr V.Revishchin², Galina V.Pavlova², \\ Ekaterina Y.Rybalkina ${ }^{3}$, Aleksandr I.Bastrakov ${ }^{1}$, Nina A.Ushakova ${ }^{1}$ \\ ${ }^{1}$ Severstov Institute of Ecology and Evolution, Russian Academy of Sciences, \\ 2Institute of Higher Nervous Activity and Neurophysiology, Russian Academy of Sciences, \\ ${ }^{3}$ Blokhin Russian Cancer Research Center, Ministry of Health of the Russian Federation; \\ Moscow, Russia \\ * Correspondence: V.M.Kovalzon, somnolog43@gmail.com Tel.: 74959541511
}

\begin{abstract}
The effect of aqueous extracts of the biomass of the adult Ulomoides dermestoides beetle on the delayed effects of the defoliant paraquat causing parkinsonism in experimental mice was evaluated. The motor activity of the animals was analyzed in behavioral tests using a rotarod and a vertical pole. The number of tyrosine hydroxylase-immunopositive neurons in the ventral part of the substantia nigra of the midbrains of experimental and control mice was studied by immunohistochemistry. In the model in vitro system with SH-SY5Y human neuroblastoma, the effect of the extracts on cell proliferation was examined in the absence and presence of the neurotoxin MPP+. The isolation of biologically active substances from raw biomass using cavitation effects made it possible to obtain extracts with protective properties in the model of an early stage of Parkinson's disease used in this study.
\end{abstract}

Keywords: Parkinson's disease; neurotoxic model; early stage; biologically active substances from insects

\section{Introduction}

Parkinson's disease (PD) is a chronic progressive degenerative disease of the central nervous system, which clinically manifests itself, in particular, as impaired coordination of movements. PD is one of the most socially significant diseases, and the study of its biological foundations is the most important task of neurosciences. In this disease, for unknown reasons, a very slow (over tens of years) but steady degeneration of dopaminergic neurons of the substantia nigra/pars compacta of the midbrain (SNpc), projected onto the neurons of striatum nuclei, occurs. The process is asymptomatic as a result of the activation of compensatory mechanisms. Motor impairment appears only at a late stage in the development of the disease, when less than half of the initial number of dopamine-containing neurons 
remain and the level of dopamine delivered to the striatum by these neurons drops by 4 -fold, followed by later cognitive impairment. However, by that stage it is too late to start treatment. In the history of world medicine, there has not yet been a single patient who could be healed. Modern medicine can only alleviate symptoms and slightly slow down the progression of the disease. Therefore, the creation of adequate experimental models and the search for early markers of the disease are now the primary tasks [1-5].

In this regard, the models of preclinical and early clinical stages of PD are of the greatest interest. These stages are characterized by a threshold level of degradation of the nigrostriatal dopaminergic system and the first minor impairments of motor function. Such models provide a unique opportunity to study the pathogenesis of a disease (the molecular mechanisms of neurodegeneration and neuroplasticity), to search for peripheral biomarkers as a basis for creating preclinical diagnostics, and to identify new molecular targets for pharmacotherapy and neuroprotection [6]. Of course, neuroprotective treatment can be effective only if it is started at an early stage, not later, when most of the neurons have already died [3,7-11].

Since animals are not susceptible to PD, the creation of such models is not an easy task [12]. The most common are neurotoxic models in which, in order to recreate the motor symptoms among others of a Parkinson-like state (parkinsonism) in laboratory mice, the dopaminergic systems of the brain are destroyed by central or peripheral administration of substances such as MPTP (methyl-phenyl-tetrahydropyridine), 6-hydroxydopamine (HDA) and lactacystin [11,13-20]. MPTP is a proneurotoxin that penetrates into astrocytes, and there, under the influence of the MAO-B enzyme, it is converted into the neurotoxic ion $\mathrm{MPP}^{+}$(1-methyl-4-phenyl-pyridine ion). Recently, the widespread herbicides rotenone and paraquat have also been increasingly used. The mechanism of their destructive effect on the dopaminergic system of the brain has been widely studied and published in a number of reviews [19,21-26].

Insects have long attracted the attention of researchers as a source of biologically active substances. For example, Apis mellifera bees, the larvae and adults of the large flour beetle Tenebrio molitor, carrion flies of the Calliphoridae family, Galleria mellonella wax moths and Bombyx mori silkworm contain new antimicrobial peptides, chitin-melanin complexes, flavonoids, aminoacids and organic acids [27-38]. Darkling beetles of the Tenebrionidae family, which are used in traditional medicine to treat a wide range of diseases, are of great interest. These insects synthesize protective secretions, which are a mixture of repellent and blocking chemoreceptor substances. They are found in cuticular inclusions or abdominal glands and are released when the beetles are stressed. It is believed that the secretions of these beetles are also necessary for the insect to prevent drying out and protect against pathogenic microorganisms [27, 31-33]. It has been shown that these secrets are a source of pharmacologically active compounds that are promising for the treatment of respiratory diseases [39]. There is information about the possibility of medical use of substances isolated from extracts of a representative of this family, the Ulomoides dermestoides darkling beetle; the substances have anti-inflammatory and immunomodulatory properties, as well as cytotoxicity in relation to the cells of some tumors [40-42]. We assumed that some components of the biomass of a representative of the same family, the Alphitobius diaperinus beetle, have an inhibitory activity against the delayed effects of the proneurotoxin MPTP, which causes experimental parkinsonism in C57B1/6jsto mice [43-45]. Our experiments using the model of the early clinical PD stage showed that the primary aqueous extract and, especially, the secondary aqueous-methanol extract of the biomass of this beetle had a powerful protective influence in response to the neurotoxic effect of MPTP, both according to behavioral tests and according to the results of morphocontrol. 
The present study evaluated the effect of aqueous extracts of biomass of the adult Ulomoides dermestoides beetle in relation to the delayed effects of paraquat defoliant causing early parkinsonism in experimental mice [22,23]. The motor activity of animals was analyzed in behavioral tests using a rotarod and a vertical pole [46,47]. Changes in the number of tyrosine hydroxylase (TH)-immunopositive neurons in the ventral part of the substantia nigra of the midbrain of mice were studied using immunohistochemistry [48]. In a model system with SH-SY5Y-human neuroblastoma, we examined the effect of the extracts on cell proliferation in the absence and presence of the neurotoxin $\mathrm{MPP}^{+}[49]$.

\section{Results}

The rotarod test, assessing the biological effect of beetle extracts in the diets of mice under conditions of a neurotoxic model of an early stage of Parkinson's disease, revealed (Fig. 1, Table 1) that the continuous administration of "cavitation extract" with food caused a slight, insignificant increase in the mean rotation speed that the mouse could sustain before falling down compared with the toxin control group (from $12.5 \pm 1.2$ to $15 \pm 1.6$ rpm; $\mathrm{M} \pm$ S.E.M.; p $>0.1$ ). The mean time of holding the mouse on the rotarod before falling increased significantly (from 701 to 825 sec, $p<0.05$, $\mathrm{n}=12 / 24$, U-test).

The "lightning extract" preparation caused a sharp increase in the ability of the animal to hold on the rotarod rotating both with constant and increasing speed. Improvement occurred with both parameters: rotarod rotation speed and mouse retention time (Fig. 1, Table 1). The indicators in this group did not differ from those of the intact control, with a significant difference from the toxin control group (for both indicators, $\mathrm{p}<0.001$ ).

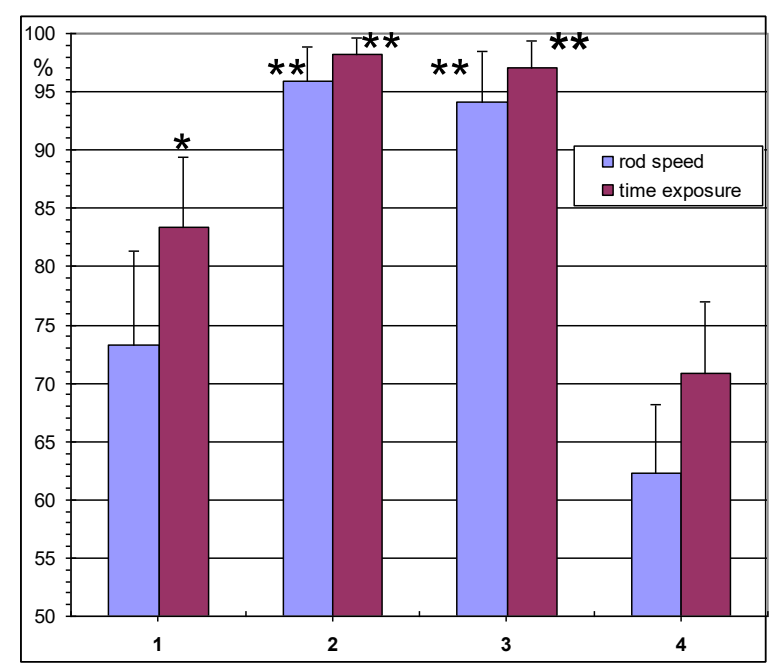

Figure 1. Results of the behavioral test on rotarod. Groups of mice: 1-toxin+"cavitation extract", $n=12$; 2-toxin+"lightning extract", $\mathrm{n}=11 ; 3$-intact control; $\mathrm{n}=12 ; 4$-toxin control, $\mathrm{n}=24$. $\mathrm{M} \pm$ S.E.M. Differences from group 4, ${ }^{*} \mathrm{p}<0.05,{ }^{* *} \mathrm{p}<0.001, \mathrm{U}$-test. The $\mathrm{y}$-scale shows the percentage of the test completion (see "Methods"). 
Table 1.

\begin{tabular}{|l|r|l|l|l|l|l|l|l|l|}
\hline & \multicolumn{2}{|c|}{ "Cavitation extract" } & \multicolumn{2}{|c|}{ "Lightning extract" } & \multicolumn{2}{|c|}{ Intact control } & \multicolumn{2}{c|}{ Paraquat control } \\
\cline { 2 - 10 } & $\begin{array}{l}\text { Rod } \\
\text { speed } \\
(\mathrm{rpm})\end{array}$ & $\begin{array}{l}\text { Time of } \\
\text { exposure } \\
(\mathrm{sec})^{\mathrm{b}}\end{array}$ & $\begin{array}{l}\text { Rod } \\
\text { speed } \\
(\mathrm{rpm})\end{array}$ & $\begin{array}{l}\text { Time of } \\
\text { exposure } \\
(\mathrm{sec})\end{array}$ & $\begin{array}{l}\text { Rod } \\
\text { Speed } \\
(\mathrm{rpm})\end{array}$ & $\begin{array}{l}\text { Time of } \\
\text { exposure } \\
(\mathrm{sec})\end{array}$ & $\begin{array}{l}\text { Rod } \\
\text { Speed } \\
(\mathrm{rpm})\end{array}$ & $\begin{array}{l}\text { Time of } \\
\text { exposure } \\
(\mathrm{sec})\end{array}$ \\
\hline Mean & 14.7 & $825.3^{*}$ & $19.2^{* *}$ & $972.9^{* *}$ & $18.8^{* *}$ & $960.9^{* *}$ & 12.5 & 700.8 \\
\hline SD & 5.6 & 208.4 & 1.9 & 42.8 & 3.0 & 77.3 & 5.8 & 300.6 \\
\hline
\end{tabular}

Note: ${ }^{a}$ revolutions per minute - an indicator of the sustained rotarod rotation speed; ${ }^{b}$ time - duration of holding the mouse on the rotarod at a rotation speed of $6 \mathrm{rpm}$.

${ }^{*} \mathrm{p}<0.05,{ }^{* *} \mathrm{p}<0.001$, difference from the paraquat-control group.

The results of intergroup comparisons of the maximum, minimum and mean durations of exposure on the vertical pole are presented in Table 2.

Table 2. Intergroup comparisons of the duration of the pole exposure (in three attempts).

\begin{tabular}{|l|l|c|}
\hline \multirow{4}{*}{ Timing parameters } & Groups in comparison & $\begin{array}{c}\text { Mean duration } \\
\text { of the pole } \\
\text { exposure (sec) }\end{array}$ \\
\hline \multirow{4}{*}{ Maximal time } & Intact control & $28.9 \pm \quad 7.2$ \\
\cline { 2 - 3 } & Toxin control & $18.1 \pm \quad 2.1$ \\
\cline { 2 - 3 } & "Cavitation extract" & $32.4 \pm \quad 5.2$ \\
\cline { 2 - 3 } & "Lightning extract" & $41.9 \pm 10.1$ \\
\hline \multirow{4}{*}{ Minimal time } & Intact control & $7.5 \pm \quad 0.6$ \\
\cline { 2 - 3 } & Toxin control & $9.9 \pm \quad 0.9$ \\
\cline { 2 - 3 } & "Cavitation extract" & $9.0 \pm 0.7$ \\
\cline { 2 - 3 } & "Lightning extract" & $12.1 \pm 0.8$ \\
\hline & Intact control & $15.4 \pm 2.5$ \\
\cline { 2 - 3 } & Toxin control & $13.6 \pm 1.4$ \\
\cline { 2 - 3 } & "Cavitation extract" & $17.8 \pm 2.0$ \\
\cline { 2 - 3 } & "Lightning extract" & $24.0 \pm 3.9$ \\
\hline
\end{tabular}

The comparison of the maximum, minimum and mean times (out of three attempts) spent by mice on the pole using the Kruskal-Wallis test showed that there were significant differences between the groups in maximal and mean times only (maximum time: $\mathrm{H} 3=10.19, \mathrm{P}=0.017$; mean time: $\mathrm{H} 3=11.10, \mathrm{P}=0.011$ ); therefore, in the statistical analysis, the minimal time is excluded from the account.

Pairwise a posteriori comparisons using the Steel-Dvas-Critchloo-Flyiner test showed that the maximal time spent on the pole was significantly higher in the "cavitation extract" group than in the toxin control group. The mean time spent on the pole was significantly higher in the "lightning extract" group than in the toxin control group (Table 3). 
Table 3.

\begin{tabular}{|c|c|c|c|}
\hline $\begin{array}{l}\text { Timing parameter } \\
\text { ratio to maximal } \\
\text { possible time of } \\
\text { pole exposure }\end{array}$ & Groups in comparison & $\begin{array}{l}\text { Criterion statistics } \\
\text { meanings } \\
\text { (Hodges-Lehmann } \\
\text { location shift) }\end{array}$ & $\begin{array}{l}\text { Significance of } \\
\text { intergroup } \\
\text { differences }(\mathrm{P})\end{array}$ \\
\hline \multirow{6}{*}{ Maximal time } & "Cavitation extract"/toxin control & 10.0 & $0.02^{*}$ \\
\hline & "Lightning extract"/toxin control & 9.2 & 0.12 \\
\hline & "Cavitation extract"/intact control & 7.6 & 0.24 \\
\hline & "Lightning extract"/intact control & 6.5 & 0.50 \\
\hline & Intact control/toxin control & 1.7 & 0.74 \\
\hline & "Cavitation extract"/"Llightning extract" & -0.2 & 0.99 \\
\hline \multirow{6}{*}{ Mean time } & "Cavitation extract"/toxin control & 4.0 & 0.08 \\
\hline & "Lightning extract"/toxin control & 6.4 & $0.04^{*}$ \\
\hline & "Cavitation extract"/intact control & 4.1 & 0.22 \\
\hline & "Lightning extract"/intact control & 6.5 & 0.10 \\
\hline & Intact control/toxin control & 0.1 & 1.00 \\
\hline & "Cavitation extract"/"Lightning extract" & 2.6 & 0.79 \\
\hline
\end{tabular}

The ratio of the maximum in three attempts to the maximum possible time spent on the pole (Table 4) in the "lightning extract" group was significantly higher than in the other groups. The same relation was significantly higher in the control group without toxin, as well as in the "cavitation extract" group, compared to the toxin control group. There were no significant differences in this parameter between the "cavitation extract" and toxin-free intact control groups. The relation of the mean exposure time on the pole to the maximal possible in three attempts in the "lightning extract" group was also significantly higher than in the other groups, and in the "cavitation extract" group compared with the toxin control group. There were no significant differences in this parameter between the other groups. 
Table 4. Pairwise intergroup comparisons of the maximum and mean ratio of exposure time on the pole versus maximum possible duration in three attempts (180 seconds) (Marasquilo's procedure at a significance level of $\alpha=0.05$ ).

\begin{tabular}{|c|c|c|c|c|c|}
\hline $\begin{array}{l}\text { Timing } \\
\text { paramete } \\
\text { rs }\end{array}$ & $\begin{array}{l}\text { Statistics } \\
\text { and } \\
\text { significance } \\
\text { in } \chi^{2}\end{array}$ & Groups in comparison & $\begin{array}{l}\text { Meaning } \\
\text { of } \\
\text { criterion } \\
\text { statistics }\end{array}$ & $\begin{array}{l}\text { Critical } \\
\text { statistical } \\
\text { value }(r)\end{array}$ & $\begin{array}{l}\text { Significance } \\
\text { of } \\
\text { intergroup } \\
\text { differences }\end{array}$ \\
\hline \multirow{6}{*}{$\begin{array}{l}\text { Maximal } \\
\text { ratio }\end{array}$} & \multirow{6}{*}{$\begin{array}{l}\chi 2=207.4 \\
P<0.000\end{array}$} & $\begin{array}{l}\text { " Cavitation } \\
\text { extract"/intact control }\end{array}$ & 0.020 & 0.029 & No \\
\hline & & $\begin{array}{l}\text { "Cavitation extract"/toxin } \\
\text { control }\end{array}$ & 0.080 & 0.027 & Yes \\
\hline & & $\begin{array}{l}\text { "Cavitation } \\
\text { extract"/"Lightning } \\
\text { extract" }\end{array}$ & 0.053 & 0.035 & Yes \\
\hline & & $\begin{array}{l}\text { Intact control/toxin } \\
\text { control }\end{array}$ & 0.060 & 0.021 & Yes \\
\hline & & $\begin{array}{l}\text { "Lightning extract"/intact } \\
\text { control }\end{array}$ & 0.072 & 0.030 & Yes \\
\hline & & $\begin{array}{l}\text { "Lightning extract"/toxin } \\
\text { control }\end{array}$ & 0.132 & 0.028 & Yes \\
\hline \multirow{6}{*}{$\begin{array}{l}\text { Mean } \\
\text { ratio }\end{array}$} & \multirow{6}{*}{$\begin{array}{l}\chi 2=61.1 \\
\mathrm{P}<0.000\end{array}$} & $\begin{array}{l}\text { "Cavitation extract"/intact } \\
\text { control }\end{array}$ & 0.013 & 0.023 & No \\
\hline & & $\begin{array}{l}\text { "Cavitation extract"/toxin } \\
\text { control }\end{array}$ & 0.024 & 0.022 & Yes \\
\hline & & $\begin{array}{l}\text { "Cavitation } \\
\text { extract"/"Lightning } \\
\text { extract" }\end{array}$ & 0.034 & 0.028 & Yes \\
\hline & & $\begin{array}{l}\text { Intact control/toxin } \\
\text { control }\end{array}$ & 0.010 & 0.017 & No \\
\hline & & $\begin{array}{l}\text { "Lightning extract"/intact } \\
\text { control }\end{array}$ & 0.048 & 0.024 & Yes \\
\hline & & $\begin{array}{l}\text { "Lightning extract"/toxin } \\
\text { control }\end{array}$ & 0.058 & 0.023 & Yes \\
\hline
\end{tabular}

In the midbrain samples of four animals from the intact control, toxin control and two "extract" groups, the number of TH-immunopositive cells was counted. The number of TH-immunopositive cells in animals that received an injection of paraquat was significantly lower than in intact control animals, as well as in animals in the "cavitation extract" and the "lightning extract" groups ( $\mathrm{H} 3=12.794, \mathrm{P}=0.005, \mathrm{Kruskal}-\mathrm{Wallis}$ test). At the same time, the number of $\mathrm{TH}$-immunopositive cells in animals from the "cavitation extract" group was significantly lower than in control intact animals and animals from the "lightning extract" group (Tables 5 and 6). 
Table 5. The mean number of TH-immunopositive cells on nine slices of substantia nigra in all studied animals.

\begin{tabular}{|c|c|c|c|c|}
\hline Nos. of mice & Intact control & Toxin control & $\begin{array}{c}\text { "Lightning } \\
\text { extract" }\end{array}$ & $\begin{array}{c}\text { "Cavitation } \\
\text { extract" }\end{array}$ \\
\hline 1 & 3992 & 2416 & 4256 & 3728 \\
\hline 2 & 4512 & 3408 & 5576 & 3448 \\
\hline 3 & 4656 & 3184 & 4016 & 3536 \\
\hline 4 & 4720 & 3232 & 4776 & 3712 \\
\hline Mean & 4470 & 3060 & 4656 & 3606 \\
\hline S.E.M. & 165 & 220 & 345 & 68 \\
\hline
\end{tabular}

Table 6. Significance of differences in the average number of TH-immunopositive cells on nine slices of substantia nigra between all studied groups of animals according to the Conover-Iman test.

\begin{tabular}{|l|r|r|r|}
\hline Compared groups & $\begin{array}{c}\text { Statistical } \\
\text { criterion } \\
\text { value (q) }\end{array}$ & $\begin{array}{c}\text { Statistical } \\
\text { criterion } \\
\text { critical } \\
\text { value }\end{array}$ & $\begin{array}{c}\text { Significance } \\
\text { of intergroup } \\
\text { difference (P) }\end{array}$ \\
\hline Intact control/toxin control & 6.58 & 2.18 & $<0.000^{*}$ \\
\hline "Lightning extract"/intact control & 0.69 & 2.18 & 0.502 \\
\hline "Cavitation extract"/intact control & 3.81 & 2.18 & $0.003^{*}$ \\
\hline "Lightning extract"/toxin control & 7.27 & 2.18 & $<0.000^{*}$ \\
\hline "Cavitation extract"/toxin control & 2.77 & 2.18 & $0.017^{*}$ \\
\hline "Cavitation extract"/"Lightning extract" & 4.50 & 2.18 & $0.001^{*}$ \\
\hline
\end{tabular}

Representative slices of the substantia nigra of the midbrain of the intact control mouse, the toxin control mouse and the "lightning extract" mouse, stained for TH, are shown in Figure 2. The number of TH-immunopositive neurons in the substantia nigra and the ventral area of the midbrain tegmentum of the toxin control mouse (middle slice) is significantly less compared to the intact control mouse (upper slice) and the animal from the "lightning extract" group (bottom slice). In the latter sample, the number of TH-immunopositive neurons in the substantia nigra and the ventral tegmental area of the midbrain is practically the same as in the intact control animal. 


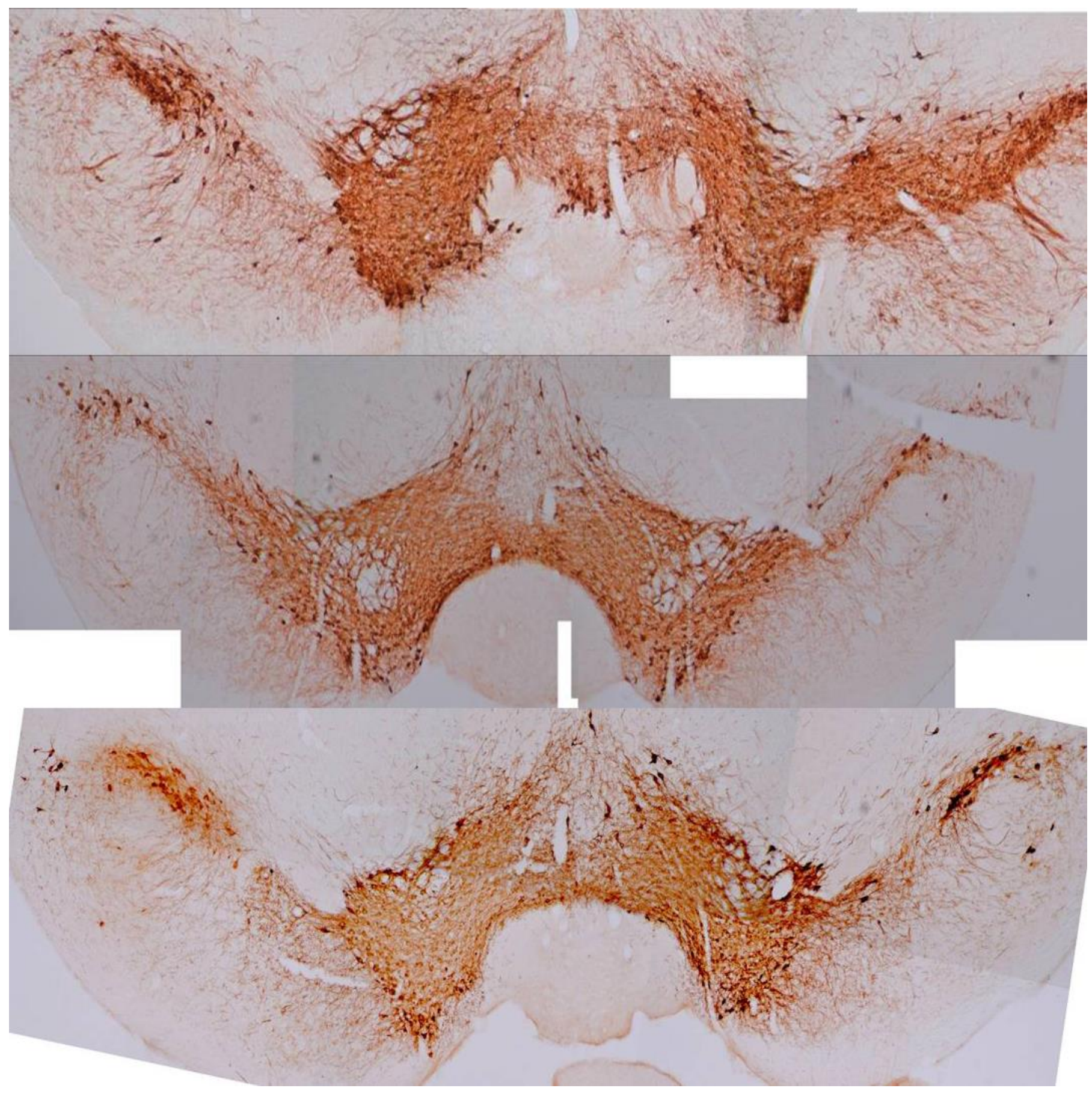

Figure 2. Representative slices of the substantia nigra of the midbrain of the animals: upper slice-intact control; middle slice-toxin control; bottom slice - “lightning extract” group. Stained for TH.

Evaluation of the protective effect of the "cavitation extract" of the Ulomoides dermestoides beetle against $0.5 \mathrm{mM}$ neurotoxin $\mathrm{MPP}^{+}$in a model experiment using SH-SY5Y neuroblastoma showed the dependence of the effect on the dose of the administered extract (Fig. 3). The best result was obtained using a 5\% addition of the extract; the protection was $23 \%$. Dilution of the extract did not cause reliable protection. 


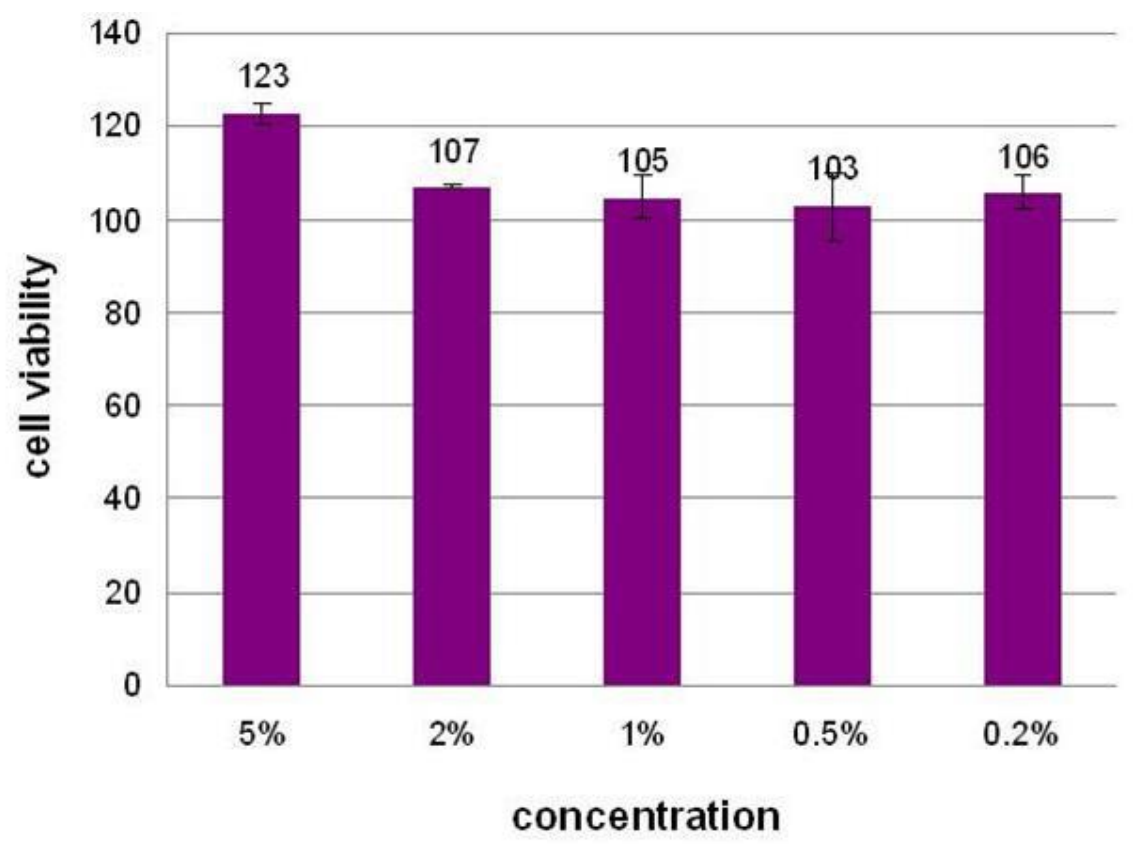

$M P P+0.5 \mathrm{mM}$

Figure 3. Protective effect of Ulomoides dermestoides "cavitation extract".

For the Ulomoides dermestoides "lightning extract", a protection of $26.5 \%$ was detected with the administration of $1 \%$ extract (Fig. 4).

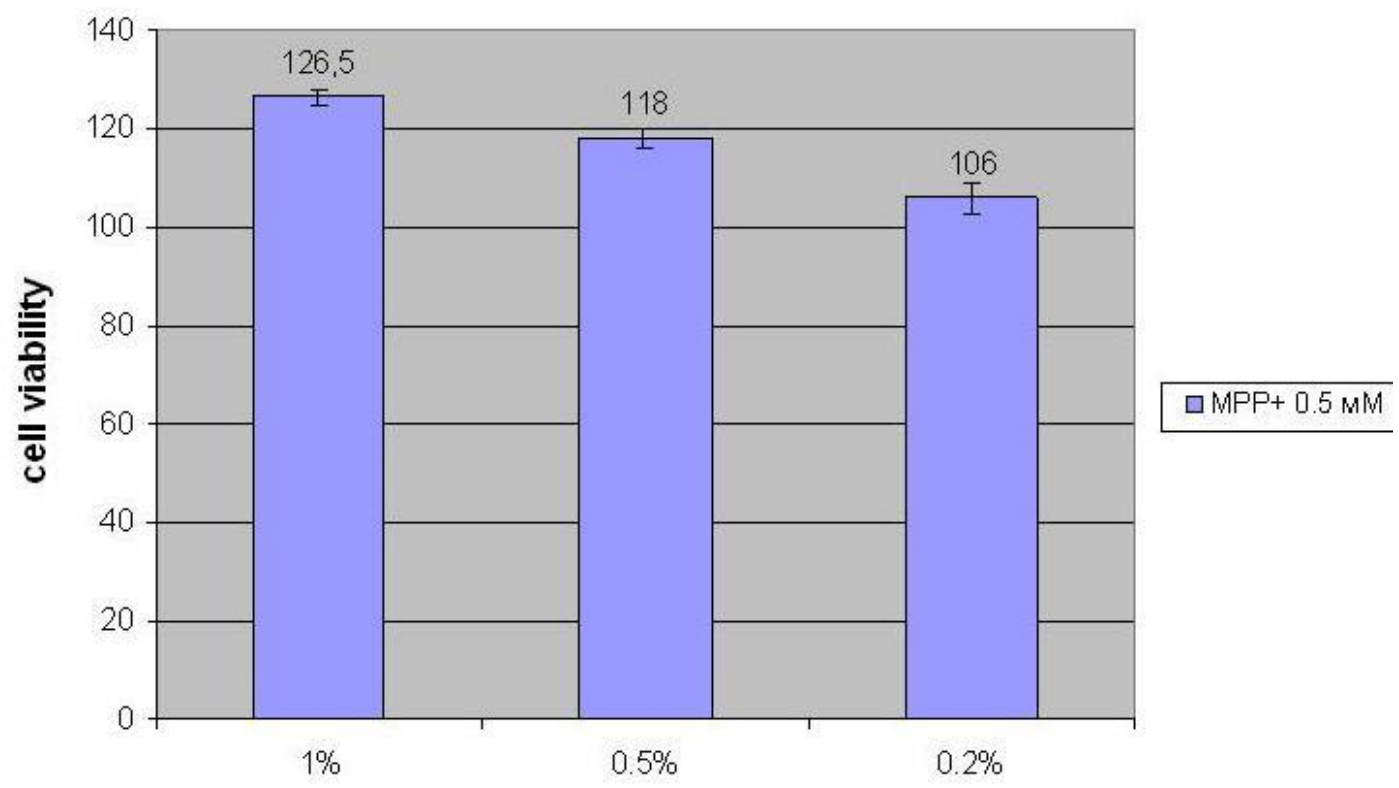

concentraition

Figure 4. Protective effect of Ulomoides dermestoides "lightning extract" on SH-SY5Y cells in the presence of MPP+ neurotoxin $(0.5 \mathrm{mM})$.

\section{Discussion}

The use of methods for the extraction of biologically active substances from the raw biomass of the Ulomoides dermestoides darkling beetle using cavitation effects, both directly and by the electroexplosive method, made it possible to obtain extracts with protective properties in the used model of an early stage of Parkinson's disease. The presented 
experiments show that the administration of the "cavitation extract" drug had some positive effect on the motor skills of animals after intoxication with paraquat compared with the control group, which was intoxicated with paraquat but did not receive the antidote. Intake of the "lightning extract" preparation with food almost completely eliminated the toxic effect of paraquat in the rotarod test. In the vertical pole test, the mice from both "extract" groups could hold on to an upright pole longer without sliding or jumping off. For this reason, the proportion of the maximum and the mean (in three attempts) times spent on the pole (from the maximal possible) in the mice of these groups was higher than in mice from the toxin control group. This is probably due to a higher muscle tone and better coordination of movements, both during locomotion and maintaining a stationary position on the supporting surface of the vertical pole. The mice from the "lightning extract" group demonstrated the best results.

The behavioral tests results were consistent with the results of histochemical examination of mouse brain slices. The significant decrease in the degree of damage to dopaminergic neurons of the compact part of the substantia nigra of the brain with paraquat toxin in the neurotoxic model of an early stage of Parkinson's disease was shown when preparations from Ulomoides dermestoides extracts were added to the food. The best results were found in animals that received the "lightning extract".

The results of the neurotoxic model of Parkinson's disease in mice were confirmed in vitro using the SH-SY5Y neuroblastoma model in the presence of the $\mathrm{MPP}^{+}$neurotoxin $(0.5 \mathrm{mM})$. Both tested beetle extracts were able to maintain cell viability by $23-26 \%$. However, this value was achieved with the introduction of $5 \%$ cavitation extract and $1 \%$ lightning extract, which correlated with the in vivo effects of the extracts in mice.

The revealed activity of extracts of the Ulomoides dermestoides darkling beetle may be associated with the presence of antioxidants and quinones [41]. Previously, it was shown that the closely related Alphitobius diaperinus darkling beetle contains the antioxidant melanin [52]. According to our latest yet unpublished studies, $1 \mathrm{mg}$ of the dry matter per $\mathrm{ml}$ of lightning extract of the Ulomoides dermestoides beetle is equivalent in antioxidant activity to $0.25 \mathrm{mM}$ trolox, a water-soluble analogue of vitamin E. Beetle extract has been shown to cause a 25-30\% increase in the average lifespan of nematodes C. elegans under normal conditions, and a $12-17 \%$ increase under oxidative stress (with paraquat), and it significantly inhibits the serum albumin fructosylation reaction. The antioxidant proteins include superoxide dismutase (SOD) and catalase, the main enzymes of the body's antioxidant system. An important role in the biological activity of the extract under oxidative stress is probably also played by heat shock proteins with molecular weights of 60,70 and $83 \mathrm{kDa}$, which protect biological systems from damaging effects under stress, including oxidative stress. The aqueous extract also includes non-protein substances with anti-infectious and anti-inflammatory properties: various phenolic compounds and ethyl-p-hydroquinone. We assume that the prophylactic activity of the extract of the Ulomoides dermestoides darkling beetle in the diet of C57B1/6jsto mice in the neurotoxic model of an early stage of Parkinson's disease is associated not with just one, but with a whole group of antioxidant and antitoxic substances contained in it.

\section{Materials and Methods}

The laboratory population of Ulomoides dermestoides beetles was cultivated at the Severstov Institute Ecology/Evolution on a nutrient mixture of wheat bran (70\%), milk powder (5\%), corn flour (20\%) and sunflower meal $(5 \%)$ in a climatic chamber at $28^{\circ} \mathrm{C}$ and $60-70 \%$ humidity, conditions similar to those for the cultivation of Alphitobius diaperinus [50]. Sexually mature adult beetles of both sexes separated from the substrate were immobilized by cooling 
at $-18^{\circ} \mathrm{C}$, and the resulting biomass was divided into two parts. One part was crushed in distilled water using cavitation on a rotary-pulsation unit followed by separation of the sediment by centrifugation in an Ohaus FRONTER 5706 for $15 \mathrm{~min}$ at $5000 \mathrm{~g}$. The received extract was named "cavitation extract". Beetle substances were extracted from the second part of the biomass by the method of electro-pulse plasma-dynamic extraction (EPPDE) in distilled water at $23^{\circ} \mathrm{C}$. EPPDE extraction was carried out using a special setup [36]. Extraction parameters: the power of the transmitted electric discharge was 38,000 Volts, the pulse frequency was one pulse per second, the distance between the electrodes was $5 \mathrm{~mm}$, the extraction time was $7 \mathrm{~min}$. After exposure, the extract was separated from the solid fraction by centrifugation at $5000 \mathrm{~g}$ for $15 \mathrm{~min}$. The received extract was named "lightning extract". Antibacterial processing of the extracts was carried out by radiation decontamination using a beam of accelerated electrons using a compact radiation sterilization unit with local biosecurity (CRSU) of the Moscow Radiotechnical Institute, Russian Academy of Sciences, at $15 \mathrm{KGy}$. The energy of the accelerated electrons was $5 \mathrm{MeV}$; the power of the electron beam was $1.5 \mathrm{~kW}$.

The "lightning extract" contained $20 \mathrm{mg} / \mathrm{ml}$ of dry matter, and the "cavitation extract" contained $12 \mathrm{mg} / \mathrm{ml}$ of dry matter. The obtained extracts were immobilized on sterile food wheat bran; the final moisture content of the mass was $8 \%$. The preparations were stored in a refrigerator and fed to experimental mice, for which dry preparations were added to the main food mixture for mice by fractional and thorough mixing (at the rate of $4 \mathrm{~g}$ of the "lightning preparation" and $8 \mathrm{~g}$ of the "cavitation preparation" per $1 \mathrm{~kg}$ of the food mixture). The main food mixture consisted of porridge, including boiled oats and peas, with the addition of vegetable oil.

To study the biological activity of the extracts, we used a neurotoxic model of an early stage of Parkinson's disease in male C57Bl/6jsto mice administered paraquat [19, 21-26]. The animals were divided into 4 groups. Group 1 ( $n=12)$ : toxin+"cavitation extract"; the animals were injected i.p. twice (with an interval of 1 week) with $10 \mathrm{mg} / \mathrm{kg}$ of paraquat, dissolved in $0.3 \mathrm{ml}$ of saline; an extract obtained by cavitation was added to the food as an antidote as described above; the supplementation began one week before the first injection of the toxin and continued throughout the entire experiment. Group 2 ( $\mathrm{n}=11$ ): toxin+"lightning extract": the animals were injected with paraquat and received the beetle extract with the food; everything was performed according to the same regimen as Group 1. Group 3 (n=12): intact control; the animals were not injected with paraquat and did not receive anything additional to the food. Group 4 $(n=24)$ : toxin-control; the animals were injected with paraquat like Groups 1 and 2, but they did not receive any antidote. Four days after the second injection of the toxin, the motor activity of all the animals was tested using a rotarod and then a vertical pole.

The mice were placed on a rod rotating at a constant speed of $6 \mathrm{rpm}$ for a period of $600 \mathrm{sec}$, then the rotation speed was increased automatically by $1 \mathrm{rpm}$ every $30 \mathrm{sec}$ up to $20 \mathrm{rpm}$. The entire duration of the test was $990 \mathrm{sec}$. We recorded how long each mouse could hold out on the rod without falling at a constant speed and at what maximum speed of rotation. If the mouse was able to stay on the rotarod for 990 seconds and did not fall at $20 \mathrm{rpm}$ within $30 \mathrm{sec}$, the test was considered $100 \%$ complete. Statistical analysis was performed using the nonparametric U-test (Mann-Whitney).

The test for locomotor activity on a vertical pole was used in accordance with the previously described method [12, 18, 46, 47]. Individual testing was performed in a familiar environment for the animals. At the beginning of testing, a vertical pole with an unpolished rough surface $50 \mathrm{~cm}$ high and $1 \mathrm{~cm}$ in diameter was placed in the cuvette. A mouse was placed on it close to the top of the pole so that its head was oriented upward. Once on the pole, the mouse reoriented its body position with its head down and began descent from the pole to the bottom of the cage. Even if the 
animal, after reorientation, did not go down the pole completely and jumped off the pole, the time it took to reach the bottom of the cage was recorded. In our variant of the method, 3 tests were carried out with each mouse. The minimum time interval between tests was 30 seconds. If the mouse did not reorient its body and start descending within the first 3 minutes from the start of testing in two or all three trials, data were not included in the statistical analysis. All the experiments were recorded using a Panasonic HC-VX1 video camera and then processed by the BORIS 7.9.8 program for the analysis and presentation of behavioral data. In the statistical analysis, only the duration of the descent of the mouse from the pole was taken into account. The groups were compared in terms of maximum and mean time of descent from the pole from three attempts. When analyzing the data, the nonparametric Kruskal-Wallis test was used. Pairwise post hoc comparisons were made using the Steel-Dvas-Critchlow-Flyiner test. In addition, intergroup comparisons were made for maximal and mean pole exposure relative to maximal possible duration in three attempts $(180 \mathrm{sec})$. The relations were compared using the $\chi^{2}$ test. For pairwise comparisons of the groups, the Marasquilo procedure was used. Statistical analysis was performed using the XLSTAT 20192.2 and Analyze-it 5.66 software.

After the completion of the behavioral tests, the animals were perfused under deep general anesthesia through the heart with phosphate buffered saline (PBS) and then $4 \%$ formaldehyde in PBS. The brain was removed, and after additional fixation in a perfusion solution for 12 hours at $4^{\circ} \mathrm{C}$, it was soaked in a 30\% sucrose solution in PBS for 24 hours. A series of coronal $20 \mu \mathrm{m}$ sections was obtained using a freezing microtome with a spacing between the sections of $160 \mu \mathrm{m}$. The sections containing substantia nigra of the midbrain were immunohistochemically stained for TH using monoclonal antibodies against TH (T2928 Sigma), diluted 1:300 in a PBS solution with the addition of 2\% normal horse serum, $0.5 \%$ Triton X100 detergent (Sigma, USA) and 0.01\% sodium azide (Sigma, USA). The free-floating sections were kept in the primary antibody solution with stirring at $4^{\circ} \mathrm{C}$ for 48 hours. Then, after the reaction in a solution of biotinylated horse antibodies against mouse immunoglobulin (Vector Laboratories USA), these sections were processed in a solution of the ABC complex (Vector Laboratories, USA). A standard procedure for staining for peroxidase was carried out using a $0.03 \%$ diaminobenzidine solution (Sigma, USA) in PBS with the addition of $0.01 \%$ hydrogen peroxide. Stained sections were placed on glass slides, covered with $50 \%$ glycerol and a cover slip.

The quantitative analysis of TH-immunopositive $\left(\mathrm{TH}^{+}\right)$cells was performed using an Olympus IX81 microscope equipped with a Märzhäuser motorized stage (FRG) computer controlled stage and an Olympus DP72 digital camera. Cells were counted on a computer monitor using the Cell* software (Olympus Soft Imaging Solution GmbH, Germany). At a low magnification (10x objective), an overview image of the section with the substantia nigra and the ventral tegmental area (VTA) was obtained. Then, at a high magnification (objective 40x), the number of $\mathrm{TH}^{+}$cells was counted using the method of an optical fractionator. The position of the test square measuring 50x50 $\mu \mathrm{m}$ was changed with a step of $200 \mu \mathrm{m}$ along the $X$ axis and $100 \mu \mathrm{m}$ along the $\mathrm{Y}$ axis within the ventral part of the midbrain. An uninformed operator counted the number of TH-immunopositive cells in the test square, using unstained nuclei of TH-immunopositive cells as the object of counting. A cell stained for TH was included in the count if its nucleus lay inside the test square or touched two of its adjacent sides (Fig. 5) and did not touch the other two sides marked in this figure with a thicker outline. Since the calculated fraction was $1 / 8$ of the area of the investigated section, to determine the total number of TH-positive cells in the section, the counted number was multiplied by 8 . Subsequently, the number of cells in 9 consecutive sections containing substantia nigra of the midbrain was determined. Intergroup comparisons of the number of TH-immunopositive cells were performed using the Kruskal-Wallis test. Since the compared samples were small, the Conover-Iman test was used for pairwise a posteriori comparisons. 


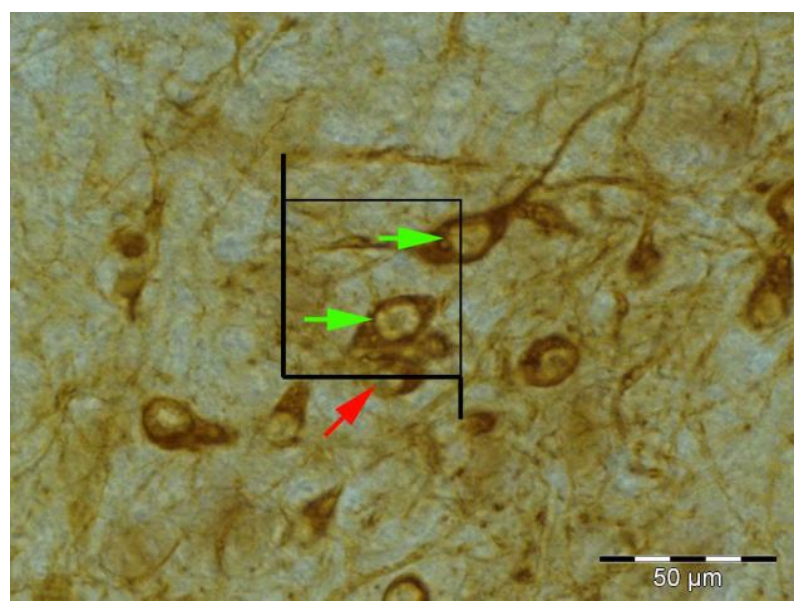

Figure 5. Representative micrograph of a TH-stained mouse brain slice with an overlaid test square. The green arrows indicate the nuclei of the cells included in the count; the red arrow indicates the nucleus of the excluded cell.

The effect of darkling beetle extract on SH-SY5Y human neuroblastoma cells was evaluated using the MTT test. This test is based on the ability of mitochondrial dehydrogenases of living cells to convert "yellow" MTT (3-(4,5-dimethylthiazolyl-2)2,5-diphenyl tetrazolium bromide) into "blue" formazan, insoluble in aqueous solutions. For analysis, cells are placed in 96-well plateaus at 5000 cells per well in $100 \mu \mathrm{l}$ of standard culture medium. After 24 hours of incubation, $10 \mu \mathrm{l}$ (1/10 of the medium volume) of the extract at various concentrations was added to the cells. The cells were incubated for another 48 or 72 hours (the incubation time depended on the rate of cell proliferation). After that, $20 \mu \mathrm{l}$ of MTT preparation (diluted in saline solution $5 \mu \mathrm{g} / \mathrm{ml}$ ) was added to each well for 3 hours. Then, the solution was removed from the wells, and $60 \mu \mathrm{l}$ of dimethyl sulfoxide (DMSO) was added to each well and they were shaken thoroughly until the formazan crystals completely dissolved. The quantitative determination of formazan was carried out on a brand multichannel photometer with a $530 \mathrm{~nm}$ filter. Cell viability was assessed by the ratio of optical density in the control wells without the tested extract and in the wells with the extract [51].

\section{Patent}

Zagorinsky, A.A.; Bastrakov, A.I.; Ushakova, N.A.; Mislavsky, B.V.; Iliev, R.L. A method of growing the darkling beetle Alphitobius diaperinus on vegetable raw materials. RF patent No. 2737117 dated 06/11/2020. Published: 24.11.2020 Bul. No. 33.

Author Contributions: Conceptualization, V.M.K. and N.A.U.; methodology, N.A.U.; software, A.V.A.; validation, A.V.R., G.V.P., E.Y.R. and A.I.B.; formal analysis, A.V.A.; investigation, N.A.U.; resources, A.I.B.; data curation, V.M.K.; writing-original draft preparation, N.A.U. and V.M.K.; writing-review and editing, V.M.K.; visualization, A.V.R. and G.V.P.; supervision, N.A.U.; project administration, N.A.U.; funding acquisition, N.A.U. All authors have read and agreed to the published version of the manuscript.

Funding: This study was funded by a private investor.

Institutional Review Board Statement: The study was conducted according to the guidelines of the Declaration of Helsinki and approved by the Institutional Ethics Committee of the Severtsov Institute of Ecology and Evolution of the Russian Academy of Sciences (Protocol Code: 009, Date of Approval: 26.10.2020).

Acknowledgments: The authors thank Roman L. Iliev and Boris V. Mislavsky for their support, and Vladimir L. Tsibulsky for reading and correcting the manuscript.

Conflicts of Interest: The authors declare no conflict of interest. 
The funders had no role in the design of the study; in the collection, analyses, or interpretation of data; in the writing of the manuscript, or in the decision to publish the results

\section{References}

1. Beitz, J.M. Parkinson's disease: a review. Frontiers in Bioscience, 2014, S6, 65-74. DOI: 10.2741/s415

2. Seidl, S.E.; Santiago, J.A.; Bilyk, H.; Potashkin, J.A. The emerging role of nutrition in Parkinson's disease. Front. Aging Neurosci., 2014, 7, 6-36.

3. Ugrumov, M. Development of early diagnosis of Parkinson's disease: Illusion or reality? CNS Neurosci. Ther., 2020, 26, 997-1009. DOI: 10.1111/cns.13429

4. Ukraintseva, Yu.V.; Kovalzon, V.M. Circadian regulation and its disorders in Parkinson's disease patients. Part 1: The role of dopamine in circadian dysfunction. Human Physiology, 2016, 42(4), 444-453. DOI: 10.1134/S0362119716040137

5. Ukraintseva, Yu.V.; Kovalzon, V.M. Circadian regulation and its disorders in Parkinson's disease patients. Part 2: Experimental models, alpha-synuclein, and melatonin. Human Physiology, 2016, 42(5), 559-570. DOI:10.1134/S0362119716050170

6. Kang, S.; Cooper, G.; Dunne, S.F.; Dusel, B.; Luan, C.H.; Surmeier, D.J.; Silverman, R.B. $\mathrm{Ca}_{\mathrm{v}}$ 1.3-selective L-type calcium channel antagonists as potential new therapeutics for Parkinson's disease. Nat. Commun., 2012, 3, 1146. DOI: 10.1038/ncomms2149 |

7. Bernheimer, H.; Birkmayer, W.; Hornykiewicz, O.; Jellinger, K.; Seitelberger, F. Brain dopamine and the syndromes of Parkinson and Huntington diseases. Clinical, morphological and neurochemical correlations. J. Neurol. Sci., 1973, 20, 415-455.

8. Bezard, E.; Gross, C.E. Compensatory mechanisms in experimental and human parkinsonism: towards a dynamic approach. Prog. Neurobiol., 1998, 55, 93-116.

9. Bezard, E.; Gross, C.E.; Brotchie, J.M. Presymptomatic compensation in Parkinson's disease is not dopamine-mediated. Trends. Neurosci., 2003, 26, 215-221.

10. Kovalzon, V.M.; Ugrumov, M.V.; Pronina, T.S.; Dorokhov, V.B.; Manolov, A.I.; Dolgikh, V.V.; Ukraintseva, Y.V.; Moiseenko, L.S.; Poluektov, M.G.; Kalinkin, A.L. Early stages of Parkinson's disease: comparative characteristics of sleep-wakefulness cycle in patients and model animals. Human Physiology, 2015, 41(6), 667-671. DOI: 10.1134/S0362119715040106

11. Ugrumov, M.V.; Khaindrava, V.G.; Kozina, E.A.; Kucheryanu, V.G.; Bocharov, E.V.; Kryzhanovsky, G.N.; Kudrin, V.S.; Narkevich, V.B.; Klodt, P.M.; Rayevsky, K.S.; Pronina, T.S. Modeling of presymptomatic and symptomatic stages of parkinsonism in mice. Neuroscience, 2011, 181, 175-188. DOI: 10.1016/j.neuroscience.2011.03.007

12. Fernagut, P.O.; Chalon, S.; Diguet, E.; Guilloteau, D.; Tison, F.; Jaber, M. Motor behaviour deficits and their histopathological and functional correlates in the nigrostriatal system of dopamine transporter knockout mice. Neuroscience, 2003, 116, 1123-1130.

13. Bezard, E.; Przedborski, S. Tale on animal models of Parkinson's disease. Movement Disorders, 2011, 26(6), 993-1002. DOI: 10.1002/mds.2369 6

14. Bergstrom, B.P.; Garris, P.A. "Passive stabilization" of striatal extracellular dopamine across the lesion spectrum encompassing the presymptomatic phase of Parkinson's disease: a voltammetric study in the 6-OHDA-lesioned rat. J. Neurochem., 2003, 87, 1224-1236.

15. Ekimova, I.V.; Plaksina, D.V.; Pastukhov, Y.F.; Lapshina, K.V.; Lazarev, V.F.; Mikhaylova, E.R.; Polonik, S.G.; Pani, B.; Margulis, B.A.; Guzhova, I.V., Nudler, E. New HSF1 inducer as a therapeutic 
agent in a rodent model of Parkinson's disease. Experimental Neurology, 2018, 306, 199-208. DOI: 10.1016/j.expneurol.2018.04.012

16. Kovalzon, V.M.; Zavalko, I.M. The neurochemistry of the sleep-wakefulness cycle and Parkinson's disease. Neurochemical Journal, 2013, 7(3), 171-183. DOI: 10.1134/S1819712413030069

17. Manolov, A.I.; Dolgikh, V.V.; Ukraintseva, Yu.V.; Zavalko, I.M.; Revishchin, A.V.; Pavlova, G.V.; Pronina, T.S.; Ugryumov, M.V.; Dorokhov, V.B.; Koval'zon, V.M. Changes in motor activity and the sleep-waking cycle in an MPTP model of Parkinson's disease in mice. Neuroscience and Behavioral Physiology, 2016, 46(4), 467-471. DOI: 10.1007/s11055-016-0259-0

18. Ogawa, N.; Mizukawa, K.; Hirose, K.; Kajita, S.; Ohara, S.; Watanabe, Y. MPTP-induced parkinsonian model in mice: biochemistry, pharmacology and behavior. Eur. Neurol., 1987, 26(Suppl. 1), $16-23$.

19. Uversky, V.N. Neurotoxicant-induced animal models of Parkinson's disease: understanding the role of rotenone, maneb and paraquat in neurodegeneration. Cell Tissue Res. 2004, 318, 225-241. DOI 10.1007/s00441-004-0937-z

20. Zigmond, M.J. Do compensatory processes underlie the preclinical phase of neurodegenerative disease? Insights from an animal model of parkinsonism. Neurobiol. Dis., 1997, 4, 247-253.

21. Bastías-Candia, S.; Di Benedetto, M.; D’Addario, C.; Candeletti, S.; Romualdi, P. Combined exposure to agriculture pesticides, paraquat and maneb, induces alterations in the N/OFQ-NOPr and PDYN/KOPr systems in rats: relevance to sporadic Parkinson's disease. Environ. Toxicol., 2015, 30, 656-663. DOI: org/10.1002/tox.21943

22. Bastías-Candia, S.; Zolezzi, J.M.; Inestrosa, N.C. Revisiting the paraquat-induced sporadic Parkinson's disease-like model. Mol. Neurobiol., 2019, 56, 1044-1055. DOI: org/10.1007/s1203, 5-018-1148-z

23. Brooks, A.I.; Chadwick, C.A.; Gelbard, H.A.; Cory-Slechta, D.A.; Federoff, H.J. Paraquat elicited neurobehavioral syndrome caused by dopaminergic neuron loss. Brain Res., 1999, 823, 1-10.

24. McCormack, A.L.; Atienza, J.G.; Johnston, L.C.; Andersen, J.K.; Vu, S.; Di Monte, D.A. Role of oxidative stress in paraquat-induced dopaminergic cell degeneration. Journal of Neurochemistry, 2005, 93, 1030-1037. doi:10.1111/j.1471-4159.2005.03088

25. McCormack, A.L.; Thiruchelvam, M.; Manning-Bog, A.B.; Thiffault, C.; Langston, J.W.; Cory-Slechta, D.A.; Di Monte, D.A. Environmental risk factors and Parkinson's disease: selective degeneration of nigral dopaminergic neurons caused by the herbicide paraquat. Neurobiol. Dis., 2002, 10, 119-127. DOI: 10.1006/nbdi.2002.0507

26. Marsova, M.; Poluektova, E.; Odorskaya, M.; Ambaryan, A.; Revishchin, A.; Pavlova, G.; Danilenko, V. Protective effects of Lactobacillus fermentum U-21 against paraquat-induced oxidative stress in Caenorhabditis elegans and mouse models. World Journal of Microbiology and Biotechnology, 2020, 36, 104. DOI: 10.1007/s11274-020-02879-2

27. Brown, W.V.; Doyen, J.T.; Moore, B.P.; Lawren, J.F. Chemical composition and taxonomic significance of defensive secretions of some Australian Tenebrionidae (Coleoptera). J. Aust. Ent. Soc., 1992, 31(1), 79-89.

28. Chernysh, S.I.; Gordja, N.A.; Simonenko N.P. Diapause and immune response: induction of antimicrobial peptides synthesis in the blowfly, Calliphora vicina R.-D. (Diptera, Calliphoridae). Entomological science, 2000, 3(1), 139-144.

29. Chernysh, S.I.; Filatova, N.A.; Chernysh, N.S.. Cytotoxic activity of blow fly Calliphora vicina hemocytes. Journal of Insect Physiology, 2004, 50, 777-781. 
30. Finke, M.D. Complete nutrient composition of commercially raised invertebrates used as food for insectivores. Zoo. Biology, 2002, 21, 269-285.

31. Geiselhardt, S.; Schmitt, T.; Peschke, K. Chemical composition and pheromonal function of the defensive secretions in the subtribe Stizopina (Coleoptera, Tenebrionidae, Opatrini). Chemoecology, 2009, 19(1), 1-6.

32. Gunbilig, D.; Boland, W. Defensive agents of Blaps femoralis, a traditional mongolian medicinal insect. Sci. Pharm., 2009, 77(3), 597-604.

33. Howard, R.W.; Jurenka, R.A.; Blomquist, G.J. Prostaglandin synthetase inhibitors in the defensive secretion of the red flour beetle Tribolium castaneum (Herbst) (Coleoptera:Tenebrionidae). Insect Biochem., 1986, 16(5), 757-760.

34. Mak, P.; Chmiel, D.; Gasek, G.J. Antibacterial peptides of the moth Galleria mellonella. Acta Biohim. Pol., 2001, 48(4), 1191-1195;

35. Naga, J.P.; Suneetha, Y.; Kumar, K.P. Ultrasound induced enhancement of protein metabolism and enzyme activities in the fat body of fifth instar silkworm, Bombyx mori L. Int. J. Pharm. Life Sci., 2014, 5(5), 3546-3553.

36. Ushakova, N.A.; Dontsov, A.E.; Marsova, M.V.; Bastrakov, A.I. Antioxidant properties of an extract of Hermetia illucens larvae. Biology Bulletin, 2021, 48(2), 118-121.

37. Zhang, Q.; Yan, S.-Q.; Li, M.-Z. Porous materials based on bombyx mori silk fibroin. Journal of Fiber Bioengineering and Informatics Review, 2010, 3(1), 1-8.

38. Zhang, Z.-T.; Cao, X.-B.; Xiong, N.; Wang, H.-C.; Huang, J.-S.; Sun, S.-G.; Wang, T. Morin exerts neuroprotective actions in Parkinson disease models in vitro and in vivo. Acta Pharmacologica Sinica. 2010, 31, 900-906.

39. Wahrendorf, M.S.; Wink, M. Pharmacologically active natural products in the defence secretion of Palembus ocularis (Tenebrionidae, Coleoptera). J. Ethnopharmacol., 2006, 106(1), 51-56.

40. Santos, R.C.V.; Lunardelli, A.; Caberlon, E.; Bastos, C.M.A.; Nunes, F.B.; Pires, M.G.S.; Biolchi, V.; Paul, E.L.; Vieira, F.B.C.; Aquino, A.R.C.; Corseuil, E.; de Oliveira, C.R. Anti-inflammatory and immunomodulatory effects of Ulomoides dermestoides on induced pleurisy in rats and lymphoproliferation in vitro. Inflammation, 33(3), 2010. DOI: 10.1007/s10753-009-9171-x

41. Crespo, R.; Villaverde, M.L.; Girotti, J.R.; Güerci, A.; Juárez, M.P.; de Bravo, M.G. Cytotoxic and genotoxic effects of defence secretion of Ulomoides dermestoides on A549 cells. J. Ethnopharmacol., 2011, 136(1), 204-209.

42. Mendoza, D.L.M.; Saavedra, S.A. Chemical composition and anti-irritant capacity of whole body extracts of Ulomoides dermestoides (coleoptera, tenebrionidae). Vitae, 2013, 20(1), 41-48.

43. Ushakova, N.A.; Kovalzon, V.M.; Bastrakov, A.I.; Kozlova, A.A.; Revishchin, A.V.; Pavlova, G.V.; Pavlov, D.S. The ability of Alphitobius diaperinus homogenates immobilized on plant sorbent to block the development of mouse parkinsonism. Doklady Biochemistry and Biophysics, 2015, 461, 94-97. DOI: 10.1134/S1607672915020088

44. Ushakova, N.A.; Kovalzon, V.M.; Shevchenko, V.P.; Nagaev, I.Yu.; Rybalkina, E.Yu.; Revishchin, A.V.; Ambaryan, A.V.; Bastrakov, A.I.; Pavlova, G.V.; Pavlov D.S. Blockage of the action of the proneurotoxin MPTP and toxin MPP+ by extracts of homogenates of Alphitobius diaperinus litter beetles in an experimental model of Parkinson's disease. Neurochemical Journal, 2018, 12(1), $78-87$. DOI: $10.1134 / \mathrm{S} 1819712418010166$

45. Koval'zon, V.M.; Ushakova, N.A.; Bastrakov, A.I.; Kozlova, A.A.; Ambaryan, A.V.; Shevchenko, V.P.; Nagaev, I.Yu.; Pavlov, D.S. Blockade of sensorimotor impairments in mice with striate 
dopaminergic deficiency by extracts of the darkling beetle Alphitobius diaperinus. Neuroscience and Behavioral Physiologyl, 2017, 47(6), 690-693. DOI: 10.1007/s11055-017-0456-5

46. Matsuura, K.; Kabuto, H.; Makino, H.; Ogawa, N. Pole test is a useful method for evaluating the mouse movement disorder caused by striatal dopamine depletion. J. Ncurosci. Methods, 1997, 73, 45-48.

47. Ogawa, N.; Hirose, K.; Ohara, S.; Ono, T.; Watanabe, Y. A simple quantitative bradykincsia test in MPTP-treated mice. Res. Commun. Chem. Pathol. Pharmacol., 1985, 50, 435-441.

48. Revishchin, A.; Moiseenko, L.; Kust, N.; Bazhenova, N.; Teslia, P.; Panteleev, D.; Kovalzon, V.; Pavlova, G. The effects of striatal implantation of cells transfected with GDNF gene without pre- and pro- regions in mouse model of Parkinson's disease. BMC Neuroscience, 2016, 17(1), 34. DOI: 10.1186/s12868-016-0271-x

49. Xicoy, H.; Wieringa, B.; Martens, G.J.M. The SH-SY5Y cell line in Parkinson's disease research: a systematic review. Molecular Neurodegeneration, 2017, 12, 10. DOI: 10.1186/s13024-017-0149-0

50. Zagorinsky, A.A.; Bastrakov, A.I.; Ushakova, N.A.; Mislavsky, B.V.; Iliev, R.L. A method of growing the darkling beetle Alphitobius diaperinus on vegetable raw materials. RF patent No. 2737117 dated 06/11/2020. Published: 24.11.2020 Bul. No. 33.

51. Mosmann, T. Rapid colorimetric assay for cellular growth and survival: application to proliferation and cytotoxicity assays. Journal of Immunological Methods, 1983, 65(1-2), 55-63.

52. Ushakova, N.A.; Dontsov, A.E.; Sakina, N.L.; Karagodin, V.P.; Bastrakov, A.I. Preparation and characterization of Alphitobius diaperinus melanin. Applied Biochemistry and Microbiology, 2018, 54(4), 425-431. DOI 10.1134/S0003683818040142 